\title{
PERFORMANCE EVALUATION OF LEADING FMCG FIRMS
}

\author{
Sri Ayan Chakraborty \\ Department of Accounting and Finance, Nopany Institute of Management Studies, India
}

\begin{abstract}
Performance of a company is evaluated with respect to its use of assets, shareholder equity and liability, revenue and expenses. Financial ratio analysis plays a significant role in evaluating the performance of a Company and comparison with peer group. A ratio is defined as "the indicated quotient of two mathematical expressions" and "the relationship between two or more things". In financial analysis, a ratio is used as a benchmark for evaluation the financial position and performance of a firm. The absolute accounting figures reported in the financial statements do not provide a meaningful understanding of the performance and financial position of a firm. An accounting figure conveys meaning when it is related to some other relevant information. In this paper, an attempt has been made to analyse the performance of 5 leading Indian FMCG companies in terms of various Financial Ratios and ANOVA. Profitability in long run contributes to sustained growth of the company. Therefore the Companies must focus on productivity and optimal resources utilization. The evaluation depicts that ITC Limited position is better in comparison to other FMCG Firms.
\end{abstract}

Keywords:

Indian FMCG Sector, Gross Profit Margin, Operating Profit Margin, Net Profit Margin, Return on Equity, Return on Capital Employed, Dividend Per Share

\section{INTRODUCTION}

Fast-Moving Consumer Goods (FMCG) sector is the fourth largest sector an important contributor to India's GDP. The FMCG industry represents nearly $2.5 \%$ of India's GDP. Indian consumer sector has grown at $5.7 \%$ (Compounded Annual Growth Rate) between 2006 and 2016. Increase in purchasing power, rising influence of the social media well established distribution network, strong presence MNCs', availability of imported Raw Materials and cheaper Labour are the key factors behind growth of the FMCG Sector. India's robust economic growth, increase in incomes is expected to increase consumer spending to $\$ 4$ trillion by 2025 , making India the third largest consumer market. The sector is highly fragmented, driven by volume and characterized by low margins as well as stiff competition between organized and unorganized players [10]. The products included under FMCG are toilet soaps, shoe polish, packaged foodstuff, detergents, shampoos, toothpaste, shaving products, household accessories and certain electronic goods.

\subsection{INDIA'S LEADING FMCG COMPANIES}

\subsubsection{Britannia Industries Limited:}

Britannia is one of the leading FMCG Company, delivering products through 3.5 million retail outlets. The primary business segment of Britannia are (i) Bakery products - Biscuit, Bread, Cake and Rusk (ii) Dairy products - Milk, Butter, Cheese, Ghee, Dahi, Milk-based ready to drink beverages and Dairy Whitener.

\subsubsection{Godrej Consumer Products Limited:}

Godrej Consumer is a leading FMCG Company engaged in the manufacture of personal and household care products. It operates in three categories - Home Care, Personal Wash and Hair Care. Godrej Consumer has a strong and emerging presence in International markets [9].

\subsubsection{ITC Limited:}

ITC Ltd is one of India's foremost private sector companies. The company is rated among the World's Best Big Companies Asia's Fab 50 and the World's Most Reputable Companies by Forbes magazine among India's Most Respected Companies by Business World and among India's Most Valuable Companies by Business Today. ITC has over 31,000 employees at more than 60 locations across India and has a strong presence in FMCG (Cigarettes, food, retail, personal care, education and stationary), Hotels, Paperboards and Specialty Papers, Packaging, AgriBusiness, and Information Technology [8].

\subsubsection{Marico Limited:}

Marico is one of India's leading consumer products \& services companies in the beauty and wellness space. Marico has a strong presence in both Indian and International market. Marico's portfolio includes brands like Parachute, Parachute Advanced, Saffola, Hair and Care, Nihar, Livon, Setwet, Zatak, Mediker and Revive [11].

\subsubsection{Hindustan Unilever Limited:}

Incorporated in 1933, Hindustan Unilever Limited has a diversified presence in the FMCG sector with more than 35 brands spanning 20 distinct categories including soaps and detergents, shampoos, skin care, toothpastes, and packaged foods. Over the years, HUL has grown substantially by acquiring landmark brands and has managed to maintain its dominant market position in various categories. HUL's portfolio includes leading household brands including Lux, Lifebuoy, Surf Excel, Rin, Wheel, Fair \& Lovely, Pond's, Vaseline and Lakme.

\subsection{OBJECTIVE OF THE STUDY}

- To analysis the financial position of some selected FMCG Companies like Britannia Industries, Godrej Consumers, ITC Ltd, Marico and Hindustan Unilever

- To highlight the financial performance and return of the selected companies using Earnings Per Share, Dividend per Share, Gross Profit Margin, Operating Profit Margin, Net Profit Margin, Return on Equity, Return on Capital Employed, Debt Equity Ratio, Debt-Asset Ratio, Interest Coverage Ratio, Current Ratio, Liquid Ratio, Dividend Per Share, Price Earnings (P/E) Ratio. 


\subsection{SCOPE OF STUDY}

The study shows the financial position of leading FMCG Companies in India. This is the process of comparing income to output and determining how much profit was made during a specific time period. A properly conducted analysis provides invaluable evidence concerning the earnings potential of a company and the effectiveness of management.

\subsection{PERIOD OF STUDY}

The study covers a period of 6 years from 2011 to 2016 .

\section{REVIEW OF LITERATURE}

The researcher and economists have recognized that the measurement of profitability in FMCG Sector is necessary to analyse and improve the financial performance of the sector. A large number of studies have been conducted in the field of operation and financial performance of FMCG Companies. A brief review of some of these studies has been presented.

Brigham and Houston's [2] financial analysis involves comparing the firm's performance to that of other firms in the same industry and evaluating trends in the firm's financial position over time. One rich source of information for financial statement analysis is the audited financial statements. The financial statements are usually part of the annual report that listed companies submit to regulatory agencies such as Securities and Exchange Commission and Stock Exchange entities.

D.H. Kantilal [3] studied on analysis of gross profit to sales ratio of top ten pharmaceutical companies and shows that there is significance difference between in the gross profit to sales ratio among different companies under study as well as different years of each company lastly the researcher concluded that Gross Profit to sales ratio among different companies and among different years under study is not same.

Ashok Kumar (2013) studied liquidity position of five leading companies which cover period of 10 years from 2000-2010. It has been found that the liquidity positions of small companies are better as compared to big ones. Lastly, it is concluded that companies should maintain an ideal current and liquid ratio.

Sarvanan and Abarna [4] conducted study on liquidity analysis of selected companies in India using ANOVA and found that there is significant difference among the absolute liquid ratios of the selected companies.

Beaver's [5] contented that standard financial ratios can predict the financial performance of firms; many subsequent studies have attempted to demonstrate the predictive value of various techniques for estimating actual business performance.

Foster [6] reviewed of the literature describing methods and theories for evaluating and predicting financial performance reveals that although methods have become increasingly complex, few researchers adequately address the problems associated with the sample used. For example, most ratio analysis studies use multivariate analysis that is based on the assumptions of normal distribution of financial ratios [1]. Without confirming the approximation of normality of ratio distribution, the researcher is at risk of drawing erroneous inferences. When considering the distribution of financial ratios in any database, the normality of the distribution can be skewed by data recording errors, negative denominators and denominators approaching zero.

Malhorta and McLeod [7] argued that the only way to assess future financial performance is through the inclusion of subjective measures.

\section{METHODOLOGY}

\subsection{SOURCES OF DATA}

The study is based on secondary data. Information required for the study has been collected from the Annual Reports of Britannia Industries, Godrej Consumers, ITC Ltd, Marico and Hindustan Unilever and different books, journal, magazines, and data collected from various websites.

\subsection{TOOLS APPLIED}

In this study various tools: Financial Tools - Ratio Analysis and Statistical Tools (i.e.) Mean and ANOVA test have been used for data analysis.

$$
\begin{gathered}
\text { Mean }=\text { Sum of variable } / N \\
\text { Standard Deviation }(S D)=\sqrt{ } \sum X^{2} / N-\left(\sum X / N\right) \\
\text { Coefficient of Variation }(C O V)=S D / \text { Mean } * 100
\end{gathered}
$$

\subsection{HYPOTHESIS}

An ANOVA is statistical hypothesis in which the sampling distribution of test statistic when null hypotheses is true. Null hypotheses have been set and adopted for the analysis of data. The null hypotheses are represented by $\mathrm{H}_{0}$. It is a negative statement which avoids personal bias of investigator during data collection as well as the time of drawing conclusion.

\subsection{LIMITATION OF THE STUDY}

- The study is related to a period of 6 years.

- As the data are only secondary i.e. they are collected from the published annual reports.

- Profitability, Structural, Liquidity and Valuation ratios have been taken for the study.

\section{A BRIEF ACCOUNT OF PROFITABILITY}

The primary objective of each business enterprise is to earn profit. In facts profit earning is considered essential not only for the survival of business but is also required for its expansion and diversification. One of the most frequently used tools of financial ratio analysis is profitability ratios which are used to determine the company's bottom line and its return to its invertors. Profitability ratios are typically based on net earnings, but variations will occasionally use cash flow or operating earnings. Profitability is a measure of efficiency and control. Profitability is the main base for liquidity as well as solvency. Creditor's, Banks and financial institutions are interested in profitability ratios since they indicate liquidity or capacity of the business to meet interest obligation and regular and improved profit to enhance the long term solvency position of the business. 
Analysing a company's profitability is an important part of financial statement analysis. Profitability of a company measures the ability to generate earnings.

Profitability ratios are classified into two main categories namely:

- Margin Ratio

- Rate of Return Ratio.

Margin Ratio: It shows the relationship between Profit and Net Sales.

Gross Margin Ratio: It shows the profit left after meeting the manufacturing expenses. It also reflects the efficiency of production by a firm.

Gross Margin Ratio $=$ Gross Profit $/$ Sales

Table.1. Gross Profit Margin (\%)

\begin{tabular}{|c|c|c|c|c|c|}
\hline Year & $\begin{array}{c}\text { Britannia } \\
\text { Industries }\end{array}$ & $\begin{array}{c}\text { Godrej } \\
\text { Consumers }\end{array}$ & ITC Ltd & Marico & HUL \\
\hline 2011 & 34.03 & 52 & 63.37 & 46.71 & 47.85 \\
\hline 2012 & 35.31 & 52.41 & 63.16 & 45.10 & 44.94 \\
\hline 2013 & 37.07 & 52.91 & 61.31 & 51.11 & 48.93 \\
\hline 2014 & 38.92 & 53.24 & 62.15 & 48.49 & 48.84 \\
\hline 2015 & 39.66 & 53.58 & 61.56 & 45.18 & 50.54 \\
\hline 2016 & 39.96 & 57.12 & 64.66 & 48.83 & 51.42 \\
\hline Mean & 37.49 & 53.54 & 62.70 & 47.57 & 48.75 \\
\hline SD & 2.44 & 1.84 & 1.27 & 2.35 & 2.27 \\
\hline COV & 0.07 & 0.03 & 0.02 & 0.049 & 0.047 \\
\hline
\end{tabular}

The Table. 1 depicts that ITC Ltd has the highest Mean Value while Britannia Industries has lowest Mean Value in comparison to other Companies. Standard deviation of Britannia Industries is 2.44, the highest while Coefficient of Variation of Britannia Industries is maximum and ITC Ltd the minimum.

\section{Hypothesis:}

$\mathbf{H}_{0}: \mu_{1}=\mu_{2}=\mu_{3}=\mu_{4}=\mu_{5}$ (There is no significant relationship between Gross Profit Margin of the above Companies)

$\mathbf{H}_{1}: \mu_{1} \neq \mu_{\mathbf{2}} \neq \mu_{\mathbf{3}} \neq \mu_{\mathbf{4}} \neq \mu_{\mathbf{5}}$ (There is significant relationship between Gross Profit Margin of the above Companies)

Table.2. Gross Profit Margin - ANOVA Single Factor

\begin{tabular}{|c|c|c|c|c|}
\hline Groups & Count & Sum & Average & Variance \\
\hline Britannia Industries & 6 & 224.948 & 37.4913 & 5.94312 \\
\hline Godrej Consumers & 6 & 321.264 & 53.544 & 3.39002 \\
\hline ITC Ltd & 6 & 376.223 & 62.7039 & 1.60457 \\
\hline Marico & 6 & 285.416 & 47.5694 & 5.49914 \\
\hline HUL & 6 & 292.507 & 48.7511 & 5.14018 \\
\hline
\end{tabular}

Table.3. ANOVA Variation

\begin{tabular}{|c|c|c|c|c|c|c|}
\hline $\begin{array}{c}\text { Source of } \\
\text { Variation }\end{array}$ & SS & df & MS & F & P-value & F crit \\
\hline $\begin{array}{c}\text { Between } \\
\text { Groups }\end{array}$ & 2027.298839 & 4 & $\begin{array}{c}506.8 \\
25\end{array}$ & $\begin{array}{c}117.4 \\
45\end{array}$ & $\begin{array}{c}8.00947 \mathrm{E}- \\
16\end{array}$ & $\begin{array}{c}2.758 \\
71\end{array}$ \\
\hline $\begin{array}{c}\text { Within } \\
\text { Groups }\end{array}$ & 107.8851336 & 25 & $\begin{array}{c}4.315 \\
41\end{array}$ & & & \\
\hline Total & 2135.183973 & 29 & & & & \\
\hline
\end{tabular}

Above analysis shows that the F-value (117.445) is more than the table value (2.75871) therefore null hypothesis is rejected. Therefore it is concluded that there is significant relationship between Gross Profit Margin of the above FMCG Companies.

Operating Margin Ratio: It shows the profit left after meeting the Operating expenses. It also reflects the Operating efficiency of a firm.

Operating Margin Ratio $=$ PBITDA/Net Sales

Table.4. Operating Profit Margin (\%)

\begin{tabular}{|c|c|c|c|c|c|}
\hline Year & $\begin{array}{c}\text { Britannia } \\
\text { Industries }\end{array}$ & $\begin{array}{c}\text { Godrej } \\
\text { Consumers }\end{array}$ & $\begin{array}{c}\text { ITC } \\
\text { Ltd }\end{array}$ & Marico & HUL \\
\hline 2011 & 4.73 & 17.73 & 36.83 & 13.10 & 15.92 \\
\hline 2012 & 5.24 & 17.58 & 38.18 & 11.92 & 16.46 \\
\hline 2013 & 6.05 & 15.31 & 38.48 & 13.39 & 19.79 \\
\hline 2014 & 7.96 & 15.22 & 40.08 & 15.77 & 18.99 \\
\hline 2015 & 10.04 & 16.50 & 40.22 & 14.99 & 20.83 \\
\hline 2016 & 13.87 & 18.11 & 42.50 & 17.32 & 19.00 \\
\hline Mean & 7.98 & 16.74 & 39.38 & 14.41 & 18.50 \\
\hline SD & 3.48 & 1.26 & 1.99 & 1.98 & 1.92 \\
\hline COV & 0.44 & 0.08 & 0.05 & 0.14 & 0.10 \\
\hline
\end{tabular}

The Table. 4 depicts that ITC Ltd has the highest Mean Value while Britannia Industries has lowest Mean Value in comparison to other FMCG Companies. Standard deviation of Britannia Industries is 3.48, the highest while Coefficient of Variation of Britannia Industries is maximum and ITC Ltd the minimum.

\section{Hypothesis:}

$\mathbf{H}_{0}: \mu_{1}=\mu_{2}=\mu_{3}=\mu_{4}=\mu_{5}$ (There is no significant relationship between Operating Profit Margin of the above Companies)

$\mathbf{H}_{1}: \mu_{\mathbf{1}} \neq \mu_{\mathbf{2}} \neq \mu_{\mathbf{3}} \neq \mu_{\mathbf{4}} \neq \mu_{\mathbf{5}}$ (There is significant relationship between Operating Profit Margin of the above Companies).

Table.5. Operating Profit Margin - ANOVA Single Factor

\begin{tabular}{|c|c|c|c|c|}
\hline Groups & Count & Sum & Average & Variance \\
\hline Britannia Industries & 6 & 47.8924 & 7.98207 & 12.1449 \\
\hline Godrej Consumers & 6 & 100.446 & 16.741 & 1.59848 \\
\hline ITC Ltd & 6 & 236.287 & 39.3811 & 3.9489 \\
\hline Marico & 6 & 86.4782 & 14.413 & 3.92261 \\
\hline HUL & 6 & 110.985 & 18.4975 & 3.68313 \\
\hline
\end{tabular}


Table.6. ANOVA Variation

\begin{tabular}{|c|c|c|c|c|c|c|}
\hline $\begin{array}{c}\text { Source of } \\
\text { Variation }\end{array}$ & SS & df & MS & F & P-value & F crit \\
\hline $\begin{array}{c}\text { Between } \\
\text { Groups }\end{array}$ & 3374.207563 & 4 & 843.552 & $\begin{array}{c}166.72 \\
3\end{array}$ & $\begin{array}{c}1.22839 \mathrm{E}- \\
17\end{array}$ & $\begin{array}{c}2.7587 \\
1\end{array}$ \\
\hline $\begin{array}{c}\text { Within } \\
\text { Groups }\end{array}$ & 126.4902861 & 25 & 5.05961 & & & \\
\hline Total & 3500.697849 & 29 & & & & \\
\hline
\end{tabular}

Above analysis shows that the F value (166.723) is more than the table value (2.75871) therefore null hypothesis is rejected. Therefore it is concluded that there is significant relationship between Operating Profit Margin of the above FMCG Companies.

Net Margin Ratio: It shows the relationship between Net profit and sales i.e. Profit left for equity shareholders as a percentage of Net sales.

Table.6. Net Profit Margin (\%)

\begin{tabular}{|c|c|c|c|c|c|}
\hline Year & $\begin{array}{c}\text { Britannia } \\
\text { Industries }\end{array}$ & $\begin{array}{c}\text { Godrej } \\
\text { Consumers }\end{array}$ & ITC Ltd & Marico & HUL \\
\hline 2011 & 2.92 & 13.23 & 22.52 & 7.59 & 11.52 \\
\hline 2012 & 3.66 & 11.29 & 23.90 & 8.04 & 11.95 \\
\hline 2013 & 4.23 & 10.97 & 24.29 & 7.91 & 14.22 \\
\hline 2014 & 5.79 & 10.70 & 25.42 & 10.38 & 13.53 \\
\hline 2015 & 7.39 & 11.84 & 25.14 & 10.03 & 13.69 \\
\hline 2016 & 10.10 & 13.11 & 25.37 & 12.03 & 12.33 \\
\hline Mean & 5.68 & 11.86 & 24.44 & 9.33 & 12.87 \\
\hline SD & 2.69 & 1.09 & 1.12 & 1.76 & 1.08 \\
\hline COV & 0.47 & 0.09 & 0.05 & 0.19 & 0.08 \\
\hline
\end{tabular}

The Table. 6 depicts that ITC Ltd has the highest Mean Value while Britannia Industries has lowest Mean Value in comparison to other FMCG Companies. Standard deviation of Britannia Industries is 2.69, the highest while Coefficient of Variation of Britannia Industries is maximum and ITC Ltd the minimum.

\section{Hypothesis:}

$\mathbf{H}_{0}: \mu_{1}=\mu_{2}=\mu_{3}=\mu_{4}=\mu_{5}$ (There is no significant relationship between Net Profit Margin of the above Companies)

$\mathbf{H}_{1}: \mu_{1} \neq \mu_{2} \neq \mu_{3} \neq \mu_{\mathbf{4}} \neq \mu_{\mathbf{5}}$ (There is significant relationship between Net Profit Margin of the above Companies)

Table.7. Net Profit Margin - ANOVA Single Factor

\begin{tabular}{|c|c|c|c|c|}
\hline Groups & Count & Sum & Average & Variance \\
\hline Britannia Industries & 6 & 34.0922 & 5.68204 & 7.24372 \\
\hline Godrej Consumers & 6 & 71.1383 & 11.8564 & 1.18218 \\
\hline ITC Ltd & 6 & 146.645 & 24.4409 & 1.25905 \\
\hline Marico & 6 & 55.9714 & 9.32857 & 3.11145 \\
\hline HUL & 6 & 77.2365 & 12.8727 & 1.17572 \\
\hline
\end{tabular}

Table.8. ANOVA Variation

\begin{tabular}{|c|c|c|c|c|c|c|}
\hline $\begin{array}{c}\text { Source of } \\
\text { Variation }\end{array}$ & SS & df & MS & F & P-value & F crit \\
\hline $\begin{array}{c}\text { Between } \\
\text { Groups }\end{array}$ & 1194.689448 & 4 & $\begin{array}{c}298.67 \\
2\end{array}$ & $\begin{array}{c}106.88 \\
2\end{array}$ & $\begin{array}{c}2.43352 \\
\text { E-15 }\end{array}$ & 2.75871 \\
\hline $\begin{array}{c}\text { Within } \\
\text { Groups }\end{array}$ & 69.86061065 & 25 & $\begin{array}{c}2.7944 \\
2\end{array}$ & & & \\
\hline Total & 1264.550059 & 29 & & & & \\
\hline
\end{tabular}

Above analysis shows that the F value (106.882) is more than the table value (2.75871) therefore null hypothesis is rejected. Therefore it is concluded that there is significant relationship between Net Profit Margin of the above FMCG Companies.

Rate of Return Ratios: It reflects the relationship between profit earned and the total investments of a firm. The important Rate of Return ratios are as follows.

- Return on Equity

- Return on Capital Employed

- Return on Investments

Return on Equity (ROE): It measures the profitability of Share holders' fund.

$$
\text { ROE }=\text { Profit after Tax / Net Worth }
$$

Table.9. Return on Equity - ROE (\%)

\begin{tabular}{|c|c|c|c|c|c|}
\hline Year & $\begin{array}{c}\text { Britannia } \\
\text { Industries }\end{array}$ & $\begin{array}{c}\text { Godrej } \\
\text { Consumers }\end{array}$ & ITC Ltd & Marico & HUL \\
\hline 2011 & 44.1 & 34.8 & 30.4 & 30.3 & 85.0 \\
\hline 2012 & 54.3 & 23.0 & 32.2 & 31.0 & 83.4 \\
\hline 2013 & 54.1 & 20.3 & 32.9 & 23.2 & 103.1 \\
\hline 2014 & 58.9 & 19.8 & 32.6 & 29.0 & 119.5 \\
\hline 2015 & 56.4 & 21.4 & 30.4 & 36.0 & 104.3 \\
\hline 2016 & 55.9 & 23.4 & 29.2 & 36.9 & 82.4 \\
\hline Mean & 54.0 & 23.8 & 31.3 & 31.1 & 96.3 \\
\hline CAGR (\%) & $5 \%$ & $-8 \%$ & $-1 \%$ & $4 \%$ & $-1 \%$ \\
\hline
\end{tabular}

The Table. 9 depicts that HUL has the highest mean in terms of Return on Equity followed by Britannia Industries, ITC Ltd, Marico and Godrej Consumers. The Compounded Annual Growth Rate (CAGR \%) of Britannia Industries and Marico are positive while that of other FMCG Companies are Negative.

\section{Hypothesis:}

$\mathbf{H}_{0}: \mu_{1}=\mu_{2}=\mu_{3}=\mu_{4}=\mu_{5}$ (There is no significant relationship between Return on Equity of the above Companies)

$\mathbf{H}_{1}: \mu_{\mathbf{1}} \neq \mu_{\mathbf{2}} \neq \mu_{\mathbf{3}} \neq \mu_{\mathbf{4}} \neq \mu_{\mathbf{5}}$ (There is significant relationship between Return on Equity of the above Companies)

Table.10. Return on Equity - ANOVA Single Factor

\begin{tabular}{|c|c|c|c|c|}
\hline Groups & Count & Sum & Average & Variance \\
\hline Britannia Industries & 6 & 323.7 & 53.95 & 26.295 \\
\hline Godrej Consumers & 6 & 142.7 & 23.7833 & 31.1617 \\
\hline ITC Ltd & 6 & 187.721 & 31.2868 & 2.18507 \\
\hline
\end{tabular}




\begin{tabular}{|c|l|l|l|l|}
\hline Marico & 6 & 186.4 & 31.0667 & 25.0227 \\
\hline HUL & 6 & 577.7 & 96.2833 & 227.158 \\
\hline
\end{tabular}

Table.11. ANOVA Variation

\begin{tabular}{|c|c|c|c|c|c|c|}
\hline $\begin{array}{c}\text { Source of } \\
\text { Variation }\end{array}$ & SS & df & MS & F & P-value & F crit \\
\hline $\begin{array}{c}\text { Between } \\
\text { Groups }\end{array}$ & 21099.38461 & 4 & 5274.85 & 84.581 & $\begin{array}{c}3.73522 \\
\text { E-14 }\end{array}$ & 2.75871 \\
\hline $\begin{array}{c}\text { Within } \\
\text { Groups }\end{array}$ & 1559.110371 & 25 & 62.3644 & & & \\
\hline Total & 22658.49498 & 29 & & & & \\
\hline
\end{tabular}

Above analysis shows that the F value (84.581) is more than the table value $(2.75871)$ therefore null hypothesis is rejected. Therefore it is concluded that there is significant relationship between Return on Equity of the above FMCG Companies.

Return on Capital Employed (ROCE): It shows the relationship between Operating Profits and Capital Employed.

Table.12. Return on Capital Employed - ROCE (\%)

\begin{tabular}{|c|c|c|c|c|c|}
\hline Year & $\begin{array}{c}\text { Britannia } \\
\text { Industries }\end{array}$ & $\begin{array}{c}\text { Godrej } \\
\text { Consumers }\end{array}$ & ITC Ltd & Marico & HUL \\
\hline 2011 & 13.9 & 22.1 & 45.1 & 19.3 & 93.4 \\
\hline 2012 & 19.1 & 14.2 & 47.2 & 19.6 & 99.6 \\
\hline 2013 & 25.8 & 14.5 & 48.1 & 17.1 & 121.8 \\
\hline 2014 & 40.0 & 14.7 & 47.7 & 21.3 & 141.6 \\
\hline 2015 & 43.9 & 15.9 & 45.3 & 27.7 & 140.6 \\
\hline 2016 & 46.0 & 16.7 & 45.5 & 31.4 & 108.1 \\
\hline Mean & 31.5 & 16.4 & 46.5 & 22.7 & 117.5 \\
\hline CAGR (\%) & $27 \%$ & $-5 \%$ & $0.16 \%$ & $10 \%$ & $3 \%$ \\
\hline
\end{tabular}

The Table.12 depicts that HUL has the highest mean in terms of Return on Capital Employed followed by ITC Ltd, Britannia Industries, Marico and Godrej Consumers. The Compounded Annual Growth Rate (CAGR \%) of Britannia Industries is maximum. Only Godrej Consumers reported a negative growth of $5 \%$ between 2011 and 2016.

\section{Hypothesis:}

$\mathbf{H}_{0}: \mu_{1}=\mu_{2}=\mu_{3}=\mu_{4}=\mu_{5}$ (There is no significant relationship between Return on Capital Employed of the above Companies)

$\mathbf{H}_{1}: \mu_{1} \neq \mu_{\mathbf{2}} \neq \mu_{\mathbf{3}} \neq \mu_{\mathbf{4}} \neq \mu_{\mathbf{5}}$ (There is significant relationship between Return on Capital Employed of the above Companies)

Table.13. Return on Capital Employed - ANOVA Single Factor

\begin{tabular}{|c|c|c|c|c|}
\hline Groups & Count & Sum & Average & Variance \\
\hline Britannia Industries & 6 & 188.7 & 31.45 & 186.451 \\
\hline Godrej Consumers & 6 & 98.1 & 16.35 & 8.831 \\
\hline ITC Ltd & 6 & 278.872 & 46.4787 & 1.74043 \\
\hline Marico & 6 & 136.4 & 22.7333 & 31.0347 \\
\hline HUL & 6 & 705.14 & 117.523 & 424.112 \\
\hline
\end{tabular}

Table.14. ANOVA Variation

\begin{tabular}{|c|c|c|c|c|c|c|}
\hline $\begin{array}{c}\text { Source of } \\
\text { Variation }\end{array}$ & SS & df & MS & F & P-value & F crit \\
\hline $\begin{array}{c}\text { Between } \\
\text { Groups }\end{array}$ & 40463.19146 & 4 & $\begin{array}{c}10115 . \\
8\end{array}$ & $\begin{array}{c}77.55 \\
5\end{array}$ & $\begin{array}{c}1.01598 \\
\text { E-13 }\end{array}$ & 2.75871 \\
\hline $\begin{array}{c}\text { Within } \\
\text { Groups }\end{array}$ & 3260.845801 & 25 & $\begin{array}{c}130.43 \\
4\end{array}$ & & & \\
\hline Total & 43724.03726 & 29 & & & & \\
\hline
\end{tabular}

Above analysis shows that the $\mathrm{F}$ value (77.555) is more than the table value (2.75871) therefore null hypothesis is rejected. Therefore it is concluded that there is significant relationship between Return on Capital Employed of the above FMCG Companies.

Return on Investments: It shows the relation between Net Profits and Total Assets of a firm.

Table.15. Return on Investments - ROI (\%)

\begin{tabular}{|c|c|c|c|c|c|}
\hline Year & $\begin{array}{c}\text { Britannia } \\
\text { Industries }\end{array}$ & $\begin{array}{c}\text { Godrej } \\
\text { Consumers }\end{array}$ & ITC Ltd & Marico & HUL \\
\hline 2011 & 14.2 & 12.9 & 28.4 & 13.9 & 63.3 \\
\hline 2012 & 19.7 & 11.5 & 30.1 & 16.3 & 59.5 \\
\hline 2013 & 27.6 & 11.8 & 30.6 & 12.6 & 93.6 \\
\hline 2014 & 41.6 & 12.8 & 30.7 & 23.4 & 81.2 \\
\hline 2015 & 41.2 & 13.7 & 28.6 & 25.3 & 83.1 \\
\hline 2016 & 44.1 & 14.6 & 27.3 & 29.6 & 72.7 \\
\hline Mean & 31.4 & 12.9 & 29.3 & 20.2 & 75.6 \\
\hline $\begin{array}{c}\text { CAGR } \\
(\%)\end{array}$ & $25.5 \%$ & $2.6 \%$ & $-0.8 \%$ & $16.3 \%$ & $2.8 \%$ \\
\hline
\end{tabular}

The Table. 15 depicts that HUL has the highest mean in terms of Return on Investments followed by Britannia Industries, ITC Ltd, Marico and Godrej Consumers. The Compounded Annual Growth Rate (CAGR \%) of Britannia Industries is maximum. Only ITC Ltd reported a negative growth of $0.8 \%$ between 2011 and 2016

\section{Hypothesis:}

$\mathbf{H}_{0}: \mu_{1}=\mu_{2}=\mu_{3}=\mu_{4}=\mu_{5}$ (There is no significant relationship between Return on Investments of the above Companies)

$\mathbf{H}_{1}: \mu_{1} \neq \mu_{\mathbf{2}} \neq \mu_{\mathbf{3}} \neq \mu_{\mathbf{4}} \neq \mu_{\mathbf{5}}$ (There is significant relationship between Return on Investments of the above Companies)

Table.16. Return on Investments - ANOVA Single Factor

\begin{tabular}{|c|c|c|c|c|}
\hline Groups & Count & Sum & Average & Variance \\
\hline Britannia Industries & 6 & 188.446 & 31.4077 & 162.3 \\
\hline Godrej Consumers & 6 & 77.3463 & 12.8911 & 1.3545 \\
\hline ITC Ltd & 6 & 175.646 & 29.2744 & 1.96064 \\
\hline Marico & 6 & 121.076 & 20.1794 & 47.5668 \\
\hline HUL & 6 & 453.412 & 75.5687 & 165.735 \\
\hline
\end{tabular}


Table.17. ANOVA Variation

\begin{tabular}{|c|c|c|c|c|c|c|}
\hline $\begin{array}{c}\text { Source of } \\
\text { Variation }\end{array}$ & SS & df & MS & F & P-value & F crit \\
\hline $\begin{array}{c}\text { Between } \\
\text { Groups }\end{array}$ & 14361.07515 & 4 & $\begin{array}{c}3590.2 \\
7\end{array}$ & $\begin{array}{c}47.375 \\
4\end{array}$ & $\begin{array}{c}2.58293 \mathrm{E}- \\
11\end{array}$ & $\begin{array}{c}2.7587 \\
1\end{array}$ \\
\hline $\begin{array}{c}\text { Within } \\
\text { Groups }\end{array}$ & 1894.586805 & 25 & $\begin{array}{c}75.783 \\
5\end{array}$ & & & \\
\hline Total & 16255.66196 & 29 & & & & \\
\hline
\end{tabular}

Above analysis shows that the F value (47.3754) is more than the table value (2.75871) therefore null hypothesis is rejected. Therefore it is concluded that there is significant relationship between Return on Investment of the above FMCG Companies.

\subsection{LIQUIDITY RATIOS}

It refers to the ability of a firm to honour its short term obligations. Here short term generally means one year or within the working capital cycle. The important Liquidity ratios are as follows.

Current Ratio: It measures the excess of Current assets over the Current Liabilities of an entity. Higher the Current Ratio indicates that firm can easily meet up its short term obligations with its available Current Assets. It should be noted that a firm with high proportion of Current Assets in the form of Cash and Debtors is more liquid than a firm with its maximum Current Assets in the form of Inventories, even though both have the same Current Ratio. Current Ratio also depends on the operating cycle of a firm. Longer the operating cycle, higher the Current ratio and vice versa. Normally a Current Ratio of 2:1 is acceptable.

Table.18. Current Ratio

\begin{tabular}{|c|c|c|c|c|c|}
\hline Year & $\begin{array}{c}\text { Britannia } \\
\text { Industries }\end{array}$ & $\begin{array}{c}\text { Godrej } \\
\text { Consumers }\end{array}$ & ITC Ltd & Marico & HUL \\
\hline 2011 & 1.05 & 1.88 & 1.59 & 2.36 & 0.99 \\
\hline 2012 & 1.03 & 1.79 & 1.70 & 2.11 & 0.98 \\
\hline 2013 & 0.93 & 1.70 & 1.81 & 2.14 & 0.90 \\
\hline 2014 & 0.82 & 1.48 & 1.90 & 2.00 & 0.88 \\
\hline 2015 & 1.00 & 1.61 & 2.10 & 2.07 & 0.88 \\
\hline 2016 & 1.09 & 1.72 & 1.73 & 1.96 & 0.91 \\
\hline Mean & 0.99 & 1.70 & 1.80 & 2.11 & 0.93 \\
\hline SD & 0.099 & 0.14 & 0.18 & 0.14 & 0.049 \\
\hline COV & 0.1 & 0.08 & 0.09 & 0.07 & 0.053 \\
\hline
\end{tabular}

The Table.18 depicts that Marico has the highest mean in terms of Current Ratio followed by ITC Ltd, Godrej Consumers, Britannia Industries, and HUL. Standard deviation of both ITC Ltd and Godrej Consumers are 0.14, the highest while Coefficient of Variation of Britannia Industries is maximum and HUL the minimum.

\section{Hypothesis:}

$\mathbf{H}_{0}: \mu_{1}=\mu_{2}=\mu_{3}=\mu_{4}=\mu_{5}$ (There is no significant relationship between Current Ratio of the above Companies)

$\mathbf{H}_{1}: \mu_{1} \neq \mu_{2} \neq \mu_{3} \neq \mu_{\mathbf{4}} \neq \mu_{\mathbf{5}}$ (There is significant relationship between Current Ratio of the above Companies)
Table.19. Current Ratio - ANOVA Single Factor

\begin{tabular}{|c|c|c|c|c|}
\hline Groups & Count & Sum & Average & Variance \\
\hline $\begin{array}{c}\text { Britannia } \\
\text { Industries }\end{array}$ & 6 & 5.92906 & 0.98818 & 0.00979 \\
\hline $\begin{array}{c}\text { Godrej } \\
\text { Consumers }\end{array}$ & 6 & 10.1837 & 1.69728 & 0.01954 \\
\hline ITC Ltd & 6 & 10.8296 & 1.80494 & 0.03222 \\
\hline Marico & 6 & 12.646 & 2.10766 & 0.01919 \\
\hline HUL & 6 & 5.55702 & 0.92617 & 0.00244 \\
\hline
\end{tabular}

Table.20. ANOVA Variation

\begin{tabular}{|c|c|c|c|c|c|c|}
\hline $\begin{array}{c}\text { Source of } \\
\text { Variation }\end{array}$ & SS & df & MS & F & P-value & F crit \\
\hline $\begin{array}{c}\text { Between } \\
\text { Groups }\end{array}$ & 6.553693241 & 4 & $\begin{array}{c}1.6384 \\
2\end{array}$ & $\begin{array}{c}98.476 \\
6\end{array}$ & $\begin{array}{c}6.35969 \mathrm{E}- \\
15\end{array}$ & $\begin{array}{c}2.7587 \\
1\end{array}$ \\
\hline $\begin{array}{c}\text { Within } \\
\text { Groups }\end{array}$ & 0.415942422 & 25 & $\begin{array}{c}0.0166 \\
4\end{array}$ & & & \\
\hline Total & 6.969635663 & 29 & & & & \\
\hline
\end{tabular}

Above analysis shows that the F value (98.4766) is more than the table value (2.75871) therefore null hypothesis is rejected. Therefore it is concluded that there is significant relationship between Current Ratio of the above FMCG Companies.

Liquid Ratio: It refers to the ability of a firm to meet its short term obligations.

$$
\begin{gathered}
\text { Liquid / Quick / Acid Test Ratio = (Current Assets }- \text { Stock }) \text { / } \\
\text { Current Liabilities }
\end{gathered}
$$

Table.21. Liquid Ratio

\begin{tabular}{|c|c|c|c|c|c|}
\hline Year & $\begin{array}{c}\text { Britannia } \\
\text { Industries }\end{array}$ & $\begin{array}{c}\text { Godrej } \\
\text { Consumers }\end{array}$ & ITC Ltd & Marico & HUL \\
\hline 2011 & 0.54 & 1.28 & 0.93 & 1.20 & 0.57 \\
\hline 2012 & 0.51 & 1.16 & 1.01 & 1.03 & 0.60 \\
\hline 2013 & 0.54 & 1.09 & 1.10 & 1.08 & 0.57 \\
\hline 2014 & 0.46 & 0.92 & 1.21 & 1.10 & 0.56 \\
\hline 2015 & 0.71 & 1.06 & 1.40 & 0.90 & 0.58 \\
\hline 2016 & 0.80 & 1.09 & 1.11 & 1.02 & 0.63 \\
\hline Mean & 0.592 & 1.10 & 1.13 & 1.05 & 0.587 \\
\hline SD & 0.13 & 0.12 & 0.16 & 0.10 & 0.03 \\
\hline COV & 0.22 & 0.11 & 0.14 & 0.09 & 0.04 \\
\hline
\end{tabular}

The Table.21 depicts that ITC Ltd has the highest mean in terms of Liquid Ratio followed by Godrej Consumers, Marico, Britannia Industries, and HUL. Standard deviation of both ITC Ltd is 0.16, the highest while Coefficient of Variation of ITC Ltd is maximum and HUL the minimum.

\section{Hypothesis:}

$\mathbf{H}_{0}: \mu_{1}=\mu_{2}=\mu_{3}=\mu_{4}=\mu_{5}$ (There is no significant relationship between Liquid Ratio of the above Companies)

$\mathbf{H}_{1}: \mu_{1} \neq \mu_{\mathbf{2}} \neq \mu_{\mathbf{3}} \neq \mu_{\mathbf{4}} \neq \mu_{\mathbf{5}}$ (There is significant relationship between Liquid Ratio of the above Companies) 
Table.22. Liquid Ratio - ANOVA Single Factor

\begin{tabular}{|c|c|c|c|c|}
\hline Groups & Count & Sum & Average & Variance \\
\hline Britannia Industries & 6 & 3.55381 & 0.5923 & 0.01718 \\
\hline Godrej Consumers & 6 & 6.60189 & 1.10031 & 0.01371 \\
\hline ITC Ltd & 6 & 6.75434 & 1.12572 & 0.02635 \\
\hline Marico & 6 & 6.3204 & 1.0534 & 0.00956 \\
\hline HUL & 6 & 3.51955 & 0.58659 & 0.00069 \\
\hline
\end{tabular}

Table.23. ANOVA Variation

\begin{tabular}{|c|c|c|c|c|c|c|}
\hline $\begin{array}{c}\text { Source of } \\
\text { Variation }\end{array}$ & SS & df & MS & F & P-value & F crit \\
\hline $\begin{array}{c}\text { Between } \\
\text { Groups }\end{array}$ & 1.842979674 & 4 & $\begin{array}{c}0.4607 \\
4\end{array}$ & $\begin{array}{c}34.136 \\
1\end{array}$ & $\begin{array}{c}8.58543 \mathrm{E}- \\
10\end{array}$ & $\begin{array}{c}2.7587 \\
1\end{array}$ \\
\hline $\begin{array}{c}\text { Within } \\
\text { Groups }\end{array}$ & 0.337431908 & 25 & 0.0135 & & & \\
\hline Total & 2.180411582 & 29 & & & & \\
\hline
\end{tabular}

Above analysis shows that the F value (34.1361) is more than the table value (2.75871) therefore null hypothesis is rejected. Therefore it is concluded that there is significant relationship between Liquid Ratio of the above FMCG Companies.

\subsection{LEVERAGE RATIOS}

Leverage ratios help in assessing the risk arising to a firm from the use of Debt Capital. Debt finance is always cheaper than Equity. The Debt holders get a fixed rate of interest on their funds from Pre-tax profits of an entity. The Equity shareholders do not have any fixed rate of Dividend. More over dividends are declared from the post-tax profits after the dividends of preference shareholders are given.

Leverage ratios are subdivided into two categories namely

- Structural Ratios

- Coverage or Solvency Ratios

Structural Ratios: They determine the proportion of Debt and Equity in the capital structure of a firm. The important Structural Ratios are

Debt Equity Ratio: It measures the total Debt of a company as a percentage of Equity shareholders fund.

Debt Equity Ratio = Total Debt / Equity Share Holders Fund

Table.24. Debt Equity Ratio

\begin{tabular}{|c|c|c|c|c|c|}
\hline Year & $\begin{array}{c}\text { Britannia } \\
\text { Industries }\end{array}$ & $\begin{array}{c}\text { Godrej } \\
\text { Consumers }\end{array}$ & ITC Ltd & Marico & HUL \\
\hline 2011 & 1.9 & 1.2 & 0.009 & 0.8 & 0.33 \\
\hline 2012 & 1.5 & 0.6 & 0.008 & 0.7 & 0.27 \\
\hline 2013 & 0.7 & 0.7 & 0.006 & 0.4 & 0.42 \\
\hline 2014 & 0.2 & 0.6 & 0.004 & 0.5 & 0.37 \\
\hline 2015 & 0.1 & 0.6 & 0.003 & 0.2 & 0.30 \\
\hline 2016 & 0.1 & 0.6 & 0.003 & 0.2 & 0.41 \\
\hline Mean & 0.8 & 0.7 & 0.005 & 0.5 & 0.4 \\
\hline CAGR (\%) & $-45 \%$ & $-13 \%$ & $-20.78 \%$ & $-24 \%$ & $5 \%$ \\
\hline
\end{tabular}

The Table.24 depicts that Britannia Industries has the highest Mean Value while, ITC Ltd has lowest Mean Value in comparison to other Companies. The Compounded Annual Growth Rate (CAGR \%) of all FMCG Companies are Negative except HUL.

\section{Hypothesis:}

$\mathbf{H}_{0}: \mu_{1}=\mu_{2}=\mu_{3}=\mu_{4}=\mu_{5}$ (There is no significant relationship between Debt Equity Ratio of the above Companies)

$\mathbf{H}_{1}: \mu_{1} \neq \mu_{\mathbf{2}} \neq \mu_{\mathbf{3}} \neq \mu_{\mathbf{4}} \neq \mu_{\mathbf{5}}$ (There is significant relationship between Debt Equity Ratio of the above Companies)

Table.25. Debt Equity Ratio -ANOVA Single Factor

\begin{tabular}{|c|c|c|c|c|}
\hline Groups & Count & Sum & Average & Variance \\
\hline Britannia Industries & 6 & 4.5 & 0.75 & 0.607 \\
\hline Godrej Consumers & 6 & 4.3 & 0.71667 & 0.05767 \\
\hline ITC Ltd & 6 & 0.03266 & 0.00544 & $6.2 \mathrm{E}-06$ \\
\hline Marico & 6 & 2.8 & 0.46667 & 0.06267 \\
\hline HUL & 6 & 2.10839 & 0.3514 & 0.00373 \\
\hline
\end{tabular}

Table.26. ANOVA Variation

\begin{tabular}{|c|c|c|c|c|c|c|}
\hline $\begin{array}{c}\text { Source of } \\
\text { Variation }\end{array}$ & SS & df & MS & F & P-value & F crit \\
\hline $\begin{array}{c}\text { Between } \\
\text { Groups }\end{array}$ & $\begin{array}{c}2.21051096 \\
5\end{array}$ & 4 & $\begin{array}{c}0.5526 \\
3\end{array}$ & $\begin{array}{c}3.7795 \\
7\end{array}$ & $\begin{array}{c}0.01545787 \\
1\end{array}$ & $\begin{array}{c}2.7587 \\
1\end{array}$ \\
\hline $\begin{array}{c}\text { Within } \\
\text { Groups }\end{array}$ & $\begin{array}{c}3.65536464 \\
5\end{array}$ & 25 & $\begin{array}{c}0.1462 \\
1\end{array}$ & & & \\
\hline Total & 5.86587561 & 29 & & & & \\
\hline
\end{tabular}

Above analysis shows that the F value (3.77957) is more than the table value (2.75871) therefore null hypothesis is rejected. Therefore it is concluded that there is significant relationship between Debt Equity Ratio of the above FMCG Companies.

Debt-Asset Ratio: It measures the total Debt of a company as a percentage of its total Capital Employed.

Table.27. Debt -Asset Ratio

\begin{tabular}{|c|c|c|c|c|c|}
\hline Year & $\begin{array}{c}\text { Britannia } \\
\text { Industries }\end{array}$ & $\begin{array}{c}\text { Godrej } \\
\text { Consumers }\end{array}$ & ITC Ltd & Marico & HUL \\
\hline 2011 & 0.66 & 0.54 & 0.07 & 0.46 & 0.25 \\
\hline 2012 & 0.60 & 0.41 & 0.06 & 0.41 & 0.22 \\
\hline 2013 & 0.41 & 0.44 & 0.07 & 0.31 & 0.30 \\
\hline 2014 & 0.16 & 0.41 & 0.06 & 0.34 & 0.27 \\
\hline 2015 & 0.11 & 0.40 & 0.06 & 0.19 & 0.23 \\
\hline 2016 & 0.07 & 0.37 & 0.06 & 0.14 & 0.29 \\
\hline Mean & 0.34 & 0.43 & 0.06 & 0.31 & 0.26 \\
\hline CAGR (\%) & $-35 \%$ & $-7.5 \%$ & $-0.96 \%$ & $-21 \%$ & $3.4 \%$ \\
\hline
\end{tabular}

The Table.27 depicts that Britannia Industries has the highest Mean Value while, ITC Ltd has lowest Mean Value in comparison to other Companies. The Compounded Annual Growth Rate (CAGR \%) of all FMCG Companies are Negative except HUL.

\section{Hypothesis:}

$\mathbf{H}_{0}: \mu_{1}=\mu_{2}=\mu_{3}=\mu_{4}=\mu_{5}$ (There is no significant relationship between Debt-Asset Ratio of the above Companies) 
$\mathbf{H}_{1}: \mu_{1} \neq \mu_{2} \neq \mu_{3} \neq \mu_{\mathbf{4}} \neq \mu_{\mathbf{5}}$ (There is significant relationship between Debt-Asset Ratio of the above Companies)

Table.28. Debt Asset Ratio - ANOVA Single Factor

\begin{tabular}{|c|c|c|c|c|}
\hline Groups & Count & Sum & Average & Variance \\
\hline Britannia Industries & 6 & 2.01332 & $0 ; .33555$ & 0.06532 \\
\hline Godrej Consumers & 6 & 2.56387 & 0.42731 & 0.00361 \\
\hline ITC Ltd & 6 & 0.38604 & 0.06434 & $8.4 \mathrm{E}-06$ \\
\hline Marico & 6 & 1.8741 & 0.31235 & 0.01551 \\
\hline HUL & 6 & 1.57232 & 0.26205 & 0.00113 \\
\hline
\end{tabular}

Table.29. ANOVA: Variation

\begin{tabular}{|c|c|c|c|c|c|c|}
\hline $\begin{array}{c}\text { Source of } \\
\text { Variation }\end{array}$ & SS & df & MS & F & P-value & F crit \\
\hline $\begin{array}{c}\text { Between } \\
\text { Groups }\end{array}$ & 0.435987807 & 4 & 0.109 & $\begin{array}{c}6.3681 \\
7\end{array}$ & $\begin{array}{c}0.00112169 \\
9\end{array}$ & $\begin{array}{c}2.7587 \\
1\end{array}$ \\
\hline $\begin{array}{c}\text { Within } \\
\text { Groups }\end{array}$ & 0.427897547 & 25 & $\begin{array}{c}0.0171 \\
2\end{array}$ & & & \\
\hline Total & 0.863885353 & 29 & & & & \\
\hline
\end{tabular}

Above analysis shows that the F value (6.36817) is more than the table value (2.75871) therefore null hypothesis is rejected. Therefore it is concluded that there is significant relationship between Debt-Asset Ratio of the above FMCG Companies.

Coverage/Solvency Ratio: It shows the ability of a firm to honor its long term commitments. It shows the relation between the Debt servicing commitments and the sources for meeting those obligations.

Interest Coverage Ratio: It shows the profits available to meet a firm's interest payments.

Interest Coverage Ratio $=$ PBITDA/ Interest

A high interest coverage ratio indicates that a firm has enough operating profit to meet its interest obligations.

Table.30. Interest Coverage Ratio

\begin{tabular}{|c|c|c|c|c|c|}
\hline Year & $\begin{array}{c}\text { Britannia } \\
\text { Industries }\end{array}$ & $\begin{array}{c}\text { Godrej } \\
\text { Consumers }\end{array}$ & ITC Ltd & Marico & HUL \\
\hline 2011 & 7.60 & 15.02 & 105.82 & 8.99 & $2,710.00$ \\
\hline 2012 & 8.50 & 12.80 & 114.89 & 10.48 & $2,127.05$ \\
\hline 2013 & 9.68 & 12.57 & 128.39 & 9.94 & 174.42 \\
\hline 2014 & 69.68 & 10.54 & $2,049.91$ & 21.16 & 123.33 \\
\hline 2015 & 209.17 & 13.64 & 211.83 & 36.80 & 319.66 \\
\hline 2016 & 249.10 & 16.00 & 288.93 & 52.02 & $1,319.30$ \\
\hline Mean & 92.29 & 13.43 & 483.30 & 23.23 & $1,128.96$ \\
\hline SD & 109.34 & 1.93 & 770.70 & 17.66 & $1,105.40$ \\
\hline COV & 1.18 & 0.14 & 1.59 & 0.76 & 0.98 \\
\hline
\end{tabular}

The Table.30 depicts that ITC Ltd has the highest Mean Value while Godrej Consumers has lowest Mean Value in comparison to other FMCG Companies. Standard deviation of HUL is $1,105.4$, the highest while Coefficient of Variation of ITC Ltd is maximum and Godrej Consumers the minimum.

\section{Hypothesis:}

$\mathbf{H}_{0}: \mu_{1}=\mu_{2}=\mu_{3}=\mu_{4}=\mu_{5}$ (There is no significant relationship between Interest Coverage Ratio of the above Companies)

$\mathbf{H}_{1}: \mu_{1} \neq \mu_{\mathbf{2}} \neq \mu_{\mathbf{3}} \neq \mu_{\mathbf{4}} \neq \mu_{\mathbf{5}}$ (There is significant relationship between Interest Coverage Ratio of the above Companies)

Table.31. Interest Coverage Ratio - ANOVA Single Factor

\begin{tabular}{|c|c|c|c|c|}
\hline Groups & Count & Sum & Average & Variance \\
\hline Britannia Industries & 6 & 553.73 & 92.2883 & 11955.8 \\
\hline Godrej Consumers & 6 & 80.57 & 13.4283 & 3.73314 \\
\hline ITC Ltd & 6 & 2899.77 & 483.295 & 593984 \\
\hline Marico & 6 & 139.39 & 23.2317 & 311.852 \\
\hline HUL & 6 & 6773.76 & 1128.96 & 1221901 \\
\hline
\end{tabular}

Table.32. ANOVA Variation

\begin{tabular}{|c|c|c|c|c|c|c|}
\hline $\begin{array}{c}\text { Source of } \\
\text { Variation }\end{array}$ & SS & df & MS & F & P-value & F crit \\
\hline $\begin{array}{c}\text { Between } \\
\text { Groups }\end{array}$ & $\begin{array}{c}5466024.57 \\
6\end{array}$ & 4 & $\begin{array}{c}136650 \\
6\end{array}$ & $\begin{array}{c}3.7373 \\
9\end{array}$ & $\begin{array}{c}0.0162001 \\
33\end{array}$ & $\begin{array}{c}2.7587 \\
1\end{array}$ \\
\hline $\begin{array}{c}\text { Within } \\
\text { Groups }\end{array}$ & $\begin{array}{c}9140782.99 \\
9\end{array}$ & 25 & 365631 & & & \\
\hline Total & $\begin{array}{c}14606807.5 \\
7\end{array}$ & 29 & & & & \\
\hline
\end{tabular}

Above analysis shows that the F value (3.73739) is more than the table value (2.75871) therefore null hypothesis is rejected. Therefore it is concluded that there is significant relationship between Interest Coverage Ratio of the above FMCG Companies.

Valuation Ratios: It indicates how the equity stock of a firm is assessed in the capital market.

The important valuation ratios are as follows.

- Earnings Per Share (EPS)

- Dividend Per Share (DPS)

- Price Earnings (P/E) Ratio

- Market Value to Book Value Ratio

Earnings per Share (EPS): It shows the relationship between profit after tax and number of equity shares outstanding.

Table.33. Earnings per Share (EPS)

\begin{tabular}{|c|c|c|c|c|c|}
\hline Year & $\begin{array}{c}\text { Britannia } \\
\text { Industries }\end{array}$ & $\begin{array}{c}\text { Godrej } \\
\text { Consumers }\end{array}$ & ITC Ltd & Marico & HUL \\
\hline 2011 & 11.2 & 14.4 & 6.5 & 1.9 & 10.5 \\
\hline 2012 & 16.7 & 15.6 & 8.0 & 2.6 & 11.9 \\
\hline 2013 & 21.7 & 19.1 & 9.6 & 2.8 & 14.7 \\
\hline 2014 & 33.0 & 21.9 & 11.1 & 3.8 & 16.4 \\
\hline 2015 & 47.9 & 26.7 & 12.0 & 4.4 & 16.9 \\
\hline 2016 & 70.1 & 33.2 & 12.3 & 5.6 & 19.0 \\
\hline Mean & 33.4 & 21.8 & 9.9 & 3.5 & 14.9 \\
\hline CAGR (\%) & $44 \%$ & $18 \%$ & $14 \%$ & $24 \%$ & $13 \%$ \\
\hline
\end{tabular}


The Table.33 depicts that Britannia Industries has the highest Mean Value while, Marico Ltd has lowest Mean Value in comparison to other Companies. The Compounded Annual Growth Rate (CAGR \%) of Britannia Industries is maximum followed by Marico, Godrej Consumers, ITC Ltd and HUL.

\section{Hypothesis:}

$\mathbf{H}_{0}: \mu_{1}=\mu_{2}=\mu_{3}=\mu_{4}=\mu_{5}$ (There is no significant relationship between Earnings per share of the above Companies)

$\mathbf{H}_{1}: \mu_{\mathbf{1}} \neq \mu_{\mathbf{2}} \neq \mu_{\mathbf{3}} \neq \mu_{\mathbf{4}} \neq \mu_{\mathbf{5}}$ (There is significant relationship between Earnings per share of the above Companies)

Table.34 Earnings per Share (EPS) - ANOVA Single Factor

\begin{tabular}{|c|c|c|c|c|}
\hline Groups & Count & Sum & Average & Variance \\
\hline Britannia Industries & 6 & 200.6 & 33.4333 & 493.183 \\
\hline Godrej Consumers & 6 & 130.9 & 21.8167 & 50.8937 \\
\hline ITC Ltd & 6 & 59.37 & 9.895 & 5.48315 \\
\hline Marico & 6 & 21.1 & 3.51667 & 1.83367 \\
\hline HUL & 6 & 89.4 & 14.9 & 10.292 \\
\hline
\end{tabular}

Table.35. ANOVA Variation

\begin{tabular}{|c|c|c|c|c|c|c|}
\hline $\begin{array}{c}\text { Source of } \\
\text { Variation }\end{array}$ & SS & df & MS & F & P-value & F crit \\
\hline $\begin{array}{c}\text { Between } \\
\text { Groups }\end{array}$ & 3177.193587 & 4 & $\begin{array}{c}794.29 \\
8\end{array}$ & $\begin{array}{c}7.0706 \\
7\end{array}$ & $\begin{array}{c}0.00059529 \\
9\end{array}$ & $\begin{array}{c}2.7587 \\
1\end{array}$ \\
\hline $\begin{array}{c}\text { Within } \\
\text { Groups }\end{array}$ & 2808.42575 & 25 & $\begin{array}{c}112.33 \\
7\end{array}$ & & & \\
\hline Total & 5985.619337 & 29 & & & & \\
\hline
\end{tabular}

Above analysis shows that the F value (7.07067) is more than the table value (2.75871) therefore null hypothesis is rejected. Therefore it is concluded that there is significant relationship between Earnings per share of the above FMCG Companies.

Dividend per Share (DPS): It shows the relationship between Dividend Declared and no of Equity Shares outstanding.

Table.36. Dividend per Share (DPS)

\begin{tabular}{|c|c|c|c|c|c|}
\hline Year & $\begin{array}{c}\text { Britannia } \\
\text { Industries }\end{array}$ & $\begin{array}{c}\text { Godrej } \\
\text { Consumers }\end{array}$ & ITC Ltd & Marico & HUL \\
\hline 2011 & 6.5 & 5.0 & 5.0 & 0.3 & 6.8 \\
\hline 2012 & 8.5 & 1.7 & 4.5 & 0.3 & 7.5 \\
\hline 2013 & 8.5 & 5.0 & 4.5 & 0.3 & 18.5 \\
\hline 2014 & 12.0 & 5.3 & 5.3 & 2.0 & 13.0 \\
\hline 2015 & 16.0 & 7.1 & 6.1 & 1.2 & 15.0 \\
\hline 2016 & 20.0 & 9.7 & 6.9 & 3.4 & 16.0 \\
\hline Mean & 11.9 & 5.6 & 5.4 & 1.3 & 12.8 \\
\hline CAGR (\%) & $25 \%$ & $14 \%$ & $7 \%$ & $63 \%$ & $19 \%$ \\
\hline
\end{tabular}

The Table. 36 depicts that HUL has the highest Mean Value while, Marico has lowest Mean Value in comparison to other Companies. The Compounded Annual Growth Rate (CAGR \%) of Marico is maximum followed by Britannia Industries, HUL, Godrej Consumers and ITC Ltd.

\section{Hypothesis:}

$\mathbf{H}_{0}: \mu_{1}=\mu_{2}=\mu_{3}=\mu_{4}=\mu_{5}$ (There is no significant relationship between Dividend per Share of the above Companies)

$\mathbf{H}_{1}: \mu_{1} \neq \mu_{\mathbf{2}} \neq \mu_{\mathbf{3}} \neq \mu_{\mathbf{4}} \neq \mu_{\mathbf{5}}$ (There is significant relationship between dividends per Share of the above Companies)

Table.37. Dividend per Share (DPS) - ANOVA Single Factor

\begin{tabular}{|c|c|c|c|c|}
\hline Groups & Count & Sum & Average & Variance \\
\hline Britannia Industries & 6 & 71.5 & 11.9167 & 26.9417 \\
\hline Godrej Consumers & 6 & 33.8 & 5.63333 & 7.01467 \\
\hline ITC Ltd & 6 & 32.2135 & 5.36891 & 0.93049 \\
\hline Marico & 6 & 7.5 & 1.25 & 1.579 \\
\hline HUL & 6 & 76.75 & 12.7917 & 22.4604 \\
\hline
\end{tabular}

Table.38. ANOVA Variation

\begin{tabular}{|c|c|c|c|c|c|c|}
\hline $\begin{array}{c}\text { Source of } \\
\text { Variation }\end{array}$ & SS & df & MS & F & P-value & F crit \\
\hline $\begin{array}{c}\text { Between } \\
\text { Groups }\end{array}$ & 567.2338116 & 4 & 141.808 & $\begin{array}{c}12.032 \\
7\end{array}$ & $\begin{array}{c}1.37419 \mathrm{E}- \\
05\end{array}$ & $\begin{array}{c}2.7587 \\
1\end{array}$ \\
\hline $\begin{array}{c}\text { Within } \\
\text { Groups }\end{array}$ & 294.6312053 & 25 & 11.7852 & & & \\
\hline Total & 861.865017 & 29 & & & & \\
\hline
\end{tabular}

Above analysis shows that the F value (12.0327) is more than the table value (2.75871) therefore null hypothesis is rejected. Therefore it is concluded that there is significant relationship between dividend per share of the above FMCG Companies

Price Earnings $(\boldsymbol{P} / \boldsymbol{E})$ Ratio: It shows the relationship between the Market Price per share and the Earnings per share.

Table.39. Price Earnings (P/E) Ratio

\begin{tabular}{|c|c|c|c|c|c|}
\hline Year & $\begin{array}{c}\text { Britannia } \\
\text { Industries }\end{array}$ & $\begin{array}{c}\text { Godrej } \\
\text { Consumers }\end{array}$ & ITC Ltd & Marico & HUL \\
\hline 2011 & 26.4 & 18.5 & 23.2 & 28.3 & 24.5 \\
\hline 2012 & 28.6 & 20.1 & 25.4 & 29.5 & 26.5 \\
\hline 2013 & 23.0 & 28.1 & 27.7 & 33.9 & 27.6 \\
\hline 2014 & 22.4 & 37.6 & 29.6 & 29.3 & 32.4 \\
\hline 2015 & 26.7 & 36.9 & 29.9 & 42.9 & 38.1 \\
\hline 2016 & 40.5 & 37.0 & 25.5 & 60.2 & 45.5 \\
\hline Mean & 27.93 & 29.70 & 26.88 & 37.35 & 32.43 \\
\hline CAGR $(\%)$ & $9 \%$ & $14.9 \%$ & $1.91 \%$ & $16.3 \%$ & $13.2 \%$ \\
\hline
\end{tabular}

The Table.39 depicts that Marico has the highest Mean Value while ITC Ltd, has lowest Mean Value in comparison to other Companies. The Compounded Annual Growth Rate (CAGR \%) of Marico is maximum followed by Godrej Consumers, HUL, Britannia Industries and ITC Ltd.

\section{Hypothesis:}

$\mathbf{H}_{0}: \mu_{1}=\mu_{2}=\mu_{3}=\mu_{4}=\mu_{5}$ (There is no significant relationship between Price Earnings Ratio of the above Companies)

$\mathbf{H}_{1}: \mu_{\mathbf{1}} \neq \mu_{\mathbf{2}} \neq \mu_{\mathbf{3}} \neq \mu_{\mathbf{4}} \neq \mu_{\mathbf{5}}$ (There is significant relationship between Price Earnings Ratio of the above Companies) 
Table.40. Price Earnings (P/E) Ratio - ANOVA Single Factor

\begin{tabular}{|c|c|c|c|c|}
\hline Groups & Count & Sum & Average & Variance \\
\hline Britannia Industries & 6 & 167.6 & 27.9333 & 43.4387 \\
\hline Godrej Consumers & 6 & 178.2 & 29.7 & 77.54 \\
\hline ITC Ltd & 6 & 161.3 & 26.8833 & 6.96567 \\
\hline Marico & 6 & 224.1 & 37.35 & 154.631 \\
\hline HUL & 6 & 194.6 & 32.4333 & 64.8707 \\
\hline
\end{tabular}

Table.41. ANOVA Variation

\begin{tabular}{|c|c|c|c|c|c|c|}
\hline $\begin{array}{c}\text { Source of } \\
\text { Variation }\end{array}$ & SS & df & MS & F & P-value & F crit \\
\hline $\begin{array}{c}\text { Between } \\
\text { Groups }\end{array}$ & 421.922 & 4 & 105.481 & 1.51794 & 0.227283314 & 2.75871 \\
\hline $\begin{array}{c}\text { Within } \\
\text { Groups }\end{array}$ & 1737.23 & 25 & 69.4892 & & & \\
\hline Total & $\begin{array}{c}2159.15 \\
2\end{array}$ & 29 & & & & \\
\hline
\end{tabular}

Above analysis shows that the F value (1.51794) is less than the table value (2.75871) therefore null hypothesis is accepted. Therefore it is concluded that there is no significant relationship between Price Earnings Ratio of the above FMCG Companies

\section{CONCLUSION}

The current study on five leading FMCG companies has been conducted to examine the profitability, liquidity and sustainability of the Leading FMCG Companies by using Ratio Analysis during the period 2011 to 2016 (six years). The study reveals that:

- In terms of Margin Ratios: Gross Profit, Operating Profit and Net Profit ITC is in the top position.

- In terms of Rate of Return Ratios: Return on Equity, Return on Capital Employed, Return on Investments HUL is in the top position.

- In terms of Liquidity: Marico is in the top position (Current Ratio), while ITC is in the top position (Liquid / Acid Test Ratio).

- Structural Ratios include both Leverage and Coverage Ratios, In terms of Leverage Britannia is in the top position for both Debt Equity and Debt-Asset Ratios. In terms of Interest Coverage ITC is in the top position.
- Under Valuation Ratios: Britannia is in the top position in terms of Earnings per Share while HUL in Dividend per Share and Marico in Price Earnings Ratio.

- Composite Performance shows that ITC is in better position in comparison to other FMCG Firms.

- The study depicted that though ranking of ratios are different, but there is no statistically significant difference between the financial ratios.

\section{REFERENCES}

[1] K. Battacharyya Asish, "Introduction to Financial Statement Analysis”, Elsevier, 2009.

[2] E.F. Brigham's and J.F. Houston's, "Fundamentals of Financial Management", $12^{\text {th }}$ Edition, South Western College Pub, 2009.

[3] D. H. Kantilal, "Financial Analysis of Selected Pharmaceutical companies in India with Special Reference to Gross Profit to Sales Ratio", Indian Journal of Applied Research, Vol. 2, No. 2, pp. 5-6, 2012.

[4] S.S. Saravanan, and J. Abarna. "A Study on Liquidity Analysis of Selected Automobile Companies in India", Indian Journal of Applied Research, Vol. 4, No. 2, pp. 6-8, 2014.

[5] William H. Beaver, "Financial Ratios as Predictors of Failure", Journal of Accounting Research, Vol. 4, pp. 71111, 1966.

[6] George Foster, "Financial Statement Analysis", PrenticeHall, 1986.

[7] R.W. McLeod and D.K. Malhotra, "An Examination of the Effect of 12b-1 Plans on Mutual Fund Expense Ratios", Journal of Financial Research, Vol. 17, No. 2, pp. 231-240, 1994.

[8] Leopold Bernstein and John J Wild, "Analysis of Financial Statements", 5 $5^{\text {th }}$ Edition, McGraw-Hill Education, 1999.

[9] Bhabatosh Banerjee, "Financial Policy and Management Accounting”, PHI Learning Pvt Ltd, 2010.

[10] Prasanna Chandra, "Financial Management Theory and Practice”, 9 $9^{\text {th }}$ Edition, McGraw-Hill, 2015.

[11] Hul Marico Britannia Godrej Consumer Products, Available at: http://economictimes.indiatimes.com/topic/HULMarico-Britannia-Godrej-Consumer-Products 